\title{
The Effect of Good Corporate Governance on Company Profits
}

\author{
Hasanudin
}

Universitas Nasional, Jakarta, Indonesia

Email: hasanudinsadikin910@gmail.com

\begin{abstract}
The aim of this study is to understand and quantify the relationship between good corporate governance (GCG) and business profit development, as well as to assess the state of GCG implementation in Indonesia. The basic impact of independent board size and managerial ownership on business earnings was examined in this analysis using Return On Asset (ROA). The samples span the timeframe 2015-2019 and include banking companies listed on the Jakarta Stock Exchange (BEJ). Purposive sampling was used to achieve a sample size of 15 businesses. Analyses of data using automated applications and panel data regression techniques. The findings indicated that while an independent board of commissioners had no discernible impact on company income, administrative ownership had a favorable and discernible effect on company profits as measured by ROA metrics.
\end{abstract}

Keywords: Good Corporate Governance (GCG), Company Profits, Return On Assets (ROA), Independent Commissioners, Managerial Leadership

\section{INTRODUCTION}

Globalization has resulted in a vast number of companies globally implementing Good Corporate Governance (GCG). Good corporate governance (GCG) is a conceptual framework that regulates and operates companies that respect all stakeholders. (Darmadi, 2013). This definition emphasizes two points. To begin, the value of shareholders' rights to receive truthful and timely information; and, second, the company's duty to report all information about the company's results, ownership, and stakeholders properly, on schedule, and transparently (Dewi, 2012).

Corporate governance as a term was developed in 1922 in England by the Cadbury Committee and is found in corporate management reviews dubbed the Cadbury Report (Boyd, 1996). Corporate governance, in this context, refers to a set of mechanisms for regulating, managing, and supervising the interaction between the principal and stakeholders in compliance with relevant regulations (Maradita, 2014). Corporate governance became a topic of discussion in Indonesia in 1998, during a period of protracted crisis. Numerous groups, including economic analysts, investors, and researchers, assert that the prolonged recovery period from this crisis is the product of Indonesian companies' extremely lax implementation of Good Corporate Governance.. Since then, the government and investors have started to pay significant attention to GCG (Wibowo, 2012).

In the banking sector, fraud has been found that have an impact on fluctuating banking performance, thus hampering the increase in banking growth that has been targeted by the government. Several aspects of banking governance are not running well, so that the banking sector requires sound and sound banking performance governance (Budiarti, 2011).

The autonomous board of commissioners and administrative ownership of a corporation are used as metrics in this analysis to assess GCG compliance. The Independent Commissioner and all independent players play a critical role in the practice of Good Corporate Governance. With the contribution of these independent parties, it is hoped that it can create checks and balances, by avoiding conflicts of interest and protecting the interests of stakeholders, especially fund owners and minority shareholders (Andriyani \& Mudjiyanti, 2017). Meanwhile, the role of managerial ownership is needed so that financial sector companies have healthy, sustainable financial performance, and can protect the interests of customers, financial sector companies have healthy, sustainable financial performance, and can protect customer interests (Wardi, 2018). 


\section{LITERATURE REVIEW}

\subsection{Good Corporate Governance}

Corporate Governance, as established by the OECD (Organisation for Economic Cooperation and Development), is a mechanism for directing and controlling a business's operations. Corporate governance establishes the allocation of roles, privileges, and responsibilities to those with an interest in the company's success, including owners, the board of directors, management, and other nonshareholder stakeholder members (Sutojo \& Aldridge, 2005). Corporate governance can have five primary goals. These five priorities include safeguarding the rights and interests of shareholders, safeguarding the rights and interests of non-shareholder stakeholder members, increasing the value of the corporation and its shareholders, enhancing the board's and company management's performance and effectiveness, and enhancing the consistency of the board's and senior management's partnership (Nuswandari, 2009).

\subsection{Independent Board of Commissioners}

According to Law No. 40 of 2007, the terms of incorporation of a corporation may provide for the appointment of one (one) or more Independent Commissioners. A member of a board of directors who does not have any investment, management or share ownership links with, or any other family connection with other board of directors, directors or controlling shareholders, or relationships with the banking authority, is an independent commissioner (as defined in Law 40 of 2007 on Limited Liability Companies). The IDX requires issuers to consist of elected commissioners, representing at least $30 \%$ of their committee. An independent board of commissioners is appointed by a foreign company to ensure that the supervision procedure properely controls the compliance of the corporation with the relevant laws and regulations and offers compensation in proportion. (Putra \& Nuzula, 2017). According to the National Committee for Governance Policy (2006), the autonomous board of commissioners must have an accounting or finance experience. Independent commissioners act as a check on the board of commissioners' decision-making authority, ensuring that accurate, specific, and timely decisions are made independently (Sarafina \& Saifi, 2017).

\subsection{Managerial ownership}

Managerial equity refers to the percentage of a company's shares held by the director, executive board, and management (Maftukhah, 2013). The proportion of total shares held by all executive directors relative to total shares is used to determine managerial ownership. The larger the managerial stake holding in the business, the more aggressive management is in the interests of shareholders, as management will therefore face the repercussions if a bad decision is made (Wahyudi \& Pawestri, 2006).

Managers must be able to optimize company profits, which will later be reported to the owner of the company. With a big responsibility, of course, managers want big rewards too. Thus in the company there are two different interests, namely the interest to optimize profit for the company owner (principle) and the interest to get a large reward for the manager (agent) (Hidayah, 2015).

\subsection{Profitability as measured by ROA}

A good company performance is measured if it has a high profitability value, it will illustrate the high profitability of the company. To assess the profitability ratio, there are four important indicators, namely GPM, NPM, ROA, and TATO (Hermuningsih, 2012). This study uses the ROA indicator, where this ratio aims to measure and assess managerial ability to earn profits by allocating all total assets owned by the company.

ROA is a ratio that is used to determine a company's willingness to benefit from its overall assets (Attar \& Islahuddin, 2014). ROA quantifies a company's ability to translate revenue from returns on investment into cash. The higher the company's return on assets, the better. Certain businesses place a premium on high net profits in order to boost their return on assets.

\section{Hypothesis}

On the basis of the context outlined above, the hypothesis for this analysis can be formulated, namely:

$\mathrm{H} 1$ = The Independent Commissioner has a significant effect on ROA

H2 = Managerial ownership has an effect on ROA. 


\section{METHOD}

This research employs a methodological approach with the use of descriptive and correlational analysis. The sample for this study is companies listed on the Indonesia Stock Exchange (IDX) in the banking sector from 2015 to 2019, with a total of 15 companies chosen using the purposive sampling system according to the sampling criteria. The research technique used is the panel data regression technique.

In this study, the regression model was adjusted using the following analysis techniques:

Where:

$$
\mathrm{Y}=\mathbf{a}+\mathbf{b} 1 \mathrm{X} 1+\mathbf{b} 2 \mathrm{X} 2+\mathbf{e}
$$

Y : ROA

a : Constant

X1 : Independent Board of Commissioners (IBC)

X2 : Managerial Ownership (MO)

b1,2 : The magnitude of the regression coefficient of each independent variable

e : Error.

\section{RESULT AND DISCUSSION}

\subsection{Regression Model Determination}

In selecting the panel data regression model, there are three methods to be used, namely the Common Effect (CE), Fixed Effect (FE) and random effect (RE) methods. The $\mathrm{F}$ test and Chow test were used to determine the method between the $\mathrm{CE}$ and $\mathrm{FE}$ approaches, while the Hausman test was used to determine between the RE and FE approaches. The results of each test to determine which method to choose are described as follows:

Table 1 shows the results of the chow test in this study to determine the selected Common effect or fixed effect model. If the value is sig. (Prob.) <0.05, then the model chosen is FE and if the value is sig. (prob.) $>0.05$, then the selected model is CE. So the hypothesis proposed is: H0: The model follows the Common Effect H1: The model follows the Fixed Effect.

Table 1 Chow Test Results

\begin{tabular}{|l|c|c|c|}
\hline \multicolumn{1}{|c|}{ Effect test } & Statistic & d.f & Prob \\
\hline Cross-section F & 21.2547 & -14.56 & 0.0000 \\
\hline Cross-section Chi Square & 135.0110 & 14.00 & 0.0000 \\
\hline
\end{tabular}

Source: Processed by researchers

Based on the conclusion of the Chow Test results in table 1 above, it can be concluded that $\mathrm{H} 0$ is rejected, so the model that can be used is the fixed effect because of Prob. (p-value) Cross Section Chi-
Square $0.0000<0.05$. However, the decision to use this model is not the final result because the Hausman test still has to be tested.

Table 2 shows the results of the chow test in this study to determine the selected fixed effect or random effect model. If the value is sig. (Prob.) $<0.05$, then the model chosen is FE and if the value is sig. (prob.) $>0.05$, then the chosen model is RE.

Table 2 Hausman Test Results

\begin{tabular}{|c|c|c|c|}
\hline Test Summary & $\begin{array}{c}\text { Chi-sq } \\
\text { statistic }\end{array}$ & $\begin{array}{c}\text { Shi-sg. } \\
\text { d.f }\end{array}$ & Prob \\
\hline $\begin{array}{c}\text { Cross-section } \\
\text { random }\end{array}$ & 9.833497 & 2 & 0.0069 \\
\hline
\end{tabular}

Source: Processed by researchers

The results of the output table 2 can be concluded that the cross-section value is the value of prob. ( $\mathrm{p}$ value) $0.0073<0.05$, so that the final result chosen is the FE model.

\subsection{Panel Data Regression Analysis}

The model employs the Fixed Effect Method based on the outcomes of the experiments (FEM). As seen in Table 3, the following are the outcomes of the regression analysis :

Table 3 Results of Regression Analysis

\begin{tabular}{|c|c|c|c|}
\hline Variable & Coefficient & t-statistic & Prob \\
\hline Constant & 0.139272 & 0.836072 & 0.4063 \\
\hline IBC & -0.02744 & -0.20793 & 0.8145 \\
\hline MO & 0.027239 & 2.381425 & 0.0215 \\
\hline
\end{tabular}

Source: Processed by researchers

Based on the table above, the regression equation for this research model is:

$$
\mathrm{Y}=0.139272-0.027440 \mathrm{X} 1+0.027239 \mathrm{X} 2
$$

From the regression equation above, the constant value of 0.139 indicates the amount of the ROA variable if the independent board of commissioners variable (X1) and managerial ownership (X2) are constant or equal to zero (0). The independent board of commissioners variable (X1) has a value of 0.027 or $2.7 \%$, this means that the value of the independent board of commissioners decreases by $1 \%$, so it will decrease the ROA value by $1 \%$ or $2.7 \%$. The managerial ownership variable (X2) has a value of 0.027 . This indicates that the value of managerial ownership will increase by $1 \%$ or equal to $2.7 \%$, then the ROA value will increase by $1 \%$ or equal to $2.7 \%$. 
According to the findings of the panel data regression study, the Independent Commissioner predictor has a p-value (prob.) of $0.8145>0.05$. These findings indicate that the regression model's study hypothesis is to reject $\mathrm{H} 1$, implying that the independent board of commissioners as an independent variable has no substantial impact on ROA. While the p-value (Prob.) In the Managerial Ownership variable is $0.0215<0.05$, which means that the research hypothesis proposed from this regression model is that it has a significant effect on the growth of ROA or H1 accepted.

The findings of panel data regression analysis demonstrate that the Independent Commissioner and Managerial Ownership variables have a major impact on ROA when they are combined. The study revealed that the prob. (F-statistic) value of 0.00000.05, followed by $\mathrm{H} 2$, indicates that Managerial Ownership has a major impact on profitability concurrently (ROA).

The coefficient of decision (R2) is considered to be 0.89 or 89 percent. This demonstrates that the variables comprising an autonomous board of commissioners and managerial ownership have an 89 percent effect on the dependent variable, namely profitability (ROA), while the remaining $11 \%$ is determined by factors beyond the scope of this study model.

The Independent Board of Commissioners' association with the ROA According to the findings of the $t$ statistical test in Table 3, the independent board of commissioners variable has a relevant amount of 0.8145 , which indicates that the independent board variable has little impact on profitability as measured by ROA. This occurs in the number of independent commissioners in businesses with a high average valuation, which has an effect on the company's success decline. Along with supervising business results, the separate board of commissioners serves as an independent mediator in cases of disagreement between management and as an advisory board to the board of directors. Thus, the presence of neutral commissioners does not ensure that the corporation can adhere to GCG standards in a way that benefits the profitability ratio. Putra \& Nuzula's (2017) previous study corroborates these findings.

Meanwhile, the managerial ownership vector has a sig value of 0.02150 .05 , indicating that managerial ownership has a direct effect on the profitability (ROA) of banking firms. With increased managerial ownership, management can be more proactive in optimizing efficiency, as they have the duty to satisfy the interests of shareholders, who are none other than themselves, by lowering the company's financial burden by debt reduction. Thus, managerial ownership can serve as a motivator for the firm to boost results, especially in achieving returns that affect shareholder satisfaction and the business entity's financial performance. Candradewi \& Sedana's (2016) previous analysis substantiates the findings of this report.

\section{CONCLUSION}

It is fair to conclude that the independent Board would not have a discerning effect on profitability based on the discussion conducted in the previous pages (ROA). Meanwhile, for the period 2015-2019, management ownership of the Indonesian stock exchange banks' Return on Assets (ROA) has a positive and significant effect.

\section{REFERENCES}

[1] Aldridge, E. J., \& Sutojo, S. (2005). Good Corporate Governance. Jakarta: Damar Mulia Pustaka.

[2] Andriyani, R., \& Mudjiyanti, R. (2017). Pengaruh Tingkat Profitabilitas, Leverage, Jumlah Dewan Komisaris Independen dan Kepemilikan Institusional terhadap Pengungkapan Internet Financial Reporting (IFR) di Bursa Efek Indonesia. Kompartemen: Jurnal Ilmiah Akuntansi, 15(1).

[3] Attar, D., \& Islahuddin, M. S. (2014). Pengaruh Penerapan Manajemen Risiko terhadap Kinerja Keuangan Perbankan yang terdaftar di Bursa Efek Indonesia. Jurnal Administrasi Akuntansi: Program Pascasarjana Unsyiah, 3(1).

[4] Boyd, C. (1996). Ethics and Corporate Governance: The Issues Raised by The Cadbury Report in the United Kingdom. Journal of Business Ethics, 15(2), 167-182.

[5] Budiarti, I. (2011). Penerapan Prinsip-Prinsip Good Corporate Governance (GCG) pada Dunia Perbankan. Majalah Ilmiah UNIKOM.

[6] Candradewi, I., \& Sedana, I. B. P. (2016). Pengaruh kepemilikan manajerial, kepemilikan institusional dan dewan komisaris independen terhadap Return On Asset. E-jurnal Manajemen, 5(5).

[7] Darmadi, S. (2013). Corporate Governance Disclosure In The Annual Report. Humanomics.

[8] Dewi, N. H. U. (2012). Corporate Governance in The Effort of Increasing The Company's Value. Journal of Economics, Business, and Accountancy Ventura, 15(2), 331-342. 
[9] Hermuningsih, S. (2012). Pengaruh Profitabilitas, Size Terhadap Nilai Perusahaan Dengan Sruktur Modal Sebagai Variabel Intervening. Jurnal Siasat Bisnis, 16(2).

[10] Hidayah, N. (2015). Pengaruh Investment Opportunity Set (Ios) Dan Kepemilikan Manajerial Terhadap Nilai Perusahaan Pada Perusahaan Property Dan Real Estat Di Bursa Efek Indonesia. Jurnal Akuntansi, 19(3), 420432.1

[11] Maradita, A. (2014). Karakteristik Good Corporate Governance Pada Bank Syariah dan Bank Konvensional. Yuridika, 29(2).

[12] Nuswandari, C. (2009). Good Corporate Governance dalam Perspektif Teori Agensi. Dinamika Keuangan dan Perbankan, 1(1).

[13] Putra, A. S., \& Nuzula, N. F. (2017). Pengaruh Corporate Governance Terhadap Profitabilitas (Studi Pada Perusahaan Perbankan Yang Terdaftar Di Bursa Efek Indonesia Periode 20132015). Jurnal Administrasi Bisnis, 47(1), 103112.

[14] Sarafina, S., \& Saifi, M. (2017). Pengaruh good corporate governance terhadap kinerja keuangan dan nilai perusahaan (Studi pada Badan Usaha Milik Negara (BUMN) yang terdaftar di Bursa Efek Indonesia periode 2012-2015). Jurnal Administrasi Bisnis, 50(3), 108-117.

[15] Sugiyono. (2014). Metode Penelitian Bisnis (Pendekatan Kuantitatif \& Kualitatif).. Bandung: Alfabeta.

[16] Wahyudi, U., \& Pawestri, H. P. (2006). Implikasi struktur kepemilikan terhadap nilai perusahaan: dengan keputusan keuangan sebagai variabel intervening. Simposium Nasional Akuntansi, 9, 125.

[17] Wardi, J. (2018). Peran Kepemimpinan Dalam Kinerja Organisasi Melalui Sistem Akuntansi Manajemen Dan Sistem Pengendalian Manajemen. Jurnal Ilmiah Ekonomi Dan Bisnis, 15(1), 42-49.

[18] Wibowo, E. (2012). Implementasi Good Corporate Governance di Indonesia. Jurnal Ekonomi dan Kewirausahaan, 10(2). 